\title{
PERANAN PROKALSITONIN PADA PNEUMONIA KOMUNITAS
}

\author{
Mirza Purwitasari ${ }^{1}$, Erlina Burhan, ${ }^{2}$, Priyanti Z. Soepandi ${ }^{2}$ \\ ${ }^{1}$ PPDS I Pulmonologi Dan Ilmu Kedokteran Respirasi Fakultas Kedokteran Universitas Indonesia \\ RSUP Persahabatan, ${ }^{2}$ Departemen Pulmonologi RSUP Persahabatan
}

\begin{abstract}
Abstrak : Keterbatasan dalam mendiagnosis infeksi respirasi dari klinis, gejala penyakit dan pemeriksaan mikrobiologis, keberadaan biomarker dapat dijadikan informasi tambahan dalam meningkatkan diagnosis dan prognosis yang membantu dalam keputusan pemberian terapi. Penggunaan prokalsitonin dapat membantu diagnosis membedakan dari infeksi yang disebabkan oleh virus, menilai derajat risiko pasien dan keputusan pemberian, penghentian dan durasi antibiotik yang optimal. Pneumonia komunitas masih menjadi masalah kesehatan. Prokalsitonin pada akhir-akhir ini menjadi perhatian prognosis pada pneumonia komunitas., baik yang diakibatkan oleh bakter iatau pun bukan. Prokalsitonin juga mempunyai kemampuan yang lebih baik dari pada C-reaktif protein sebagai biomarker petanda inflamasi dan mempunyai hubungan yang signifikan dengan skor sistem yang menilai klinis dan angka kematian. Kata kunci: Pneumonia komunitas, prokalsitonin
\end{abstract}

Kata kunci: Pneumonia komunitas, prokalsitonin

\section{PROCALCITONIN ROLE OF PNEUMONIA IN COMMUNITY}

\begin{abstract}
In light of the limitations of clinical signs and symptoms and traditional microbiologic diagnostic for respiratory infections, blood biomarkers that correlate with the presence and extent of bacterial infections may provide additional useful information to improve diagnostic and prognostic efforts and help with therapeutic decisions in individual patients. A growing body of evidence support the use of procalcitonin (PCT) to differentiate bacterial from viral respiratory diagnoses, to help risk stratify patients, and to guide antibiotic therapy decisions about initial need for, and optimal duration of, therapy.Communityacquired peneumonia (CAP) is a significant clinical and public health problem. Recently, attention has been paid to the potential for procalcitonin (PCT) both to differentiate the diagnosis and to indicate the prognosis of pneumonia. Procalsitonin has the ability to supplement clinical information to determine whether or not the cause of the inection is likely to be bacterial. In addition, PCT seems to be superior to the most prevalent inflammatory biomarker C-reactive protein and also demonstrates a significant correlation between the current clinical scoring systems and actual mortality.
\end{abstract}

Key words : Community-acquired peneumonia, procalcitonin.

Korespondensi :

DR.dr.Erlina Burhan, M.Sc.SpP(K)

Departemen Pulmonologi divisi infeksi FK UI RSUP Persahabatan

Jl. Persahabatan Raya No.1, Jakarta 13230

Telepon:(021) 4891708

\section{PENDAHULUAN}

Pneumonia komunitas atau community acquired pneumonia (CAP) adalah pneumonia yang terjadi di masyarakat yang merupakan salah satu penyakit infeksi yang banyak terjadi dan penyebab kematian dan kesakitan terbanyak di dunia. Pneumonia komunitas menduduki urutan ke-3 dari 30 penyebab kematian di dunia. Angka kematian pneumonia komunitas pada rawat jalan $2 \%$, rawat inap $5-20 \%$ dan di ruang intensif $>50 \%$. Pneumonia komunitas menjadi suatu penyakit yang sangat mengancam jiwa terutama pada pasien lanjut usia dan pasien dengan penyakit komorbid seperti Penyakit Paru Obstruktif Kronik (PPOK), diabetes melitus, gagal jantung, penyakit arteri koroner, keganasan, gangguan fungsi ginjal dan penyakit hati kronik. Pneumonia di Indonesia termasuk dalam 10 besar penyakit rawat inap di rumah sakit dengan proporsi kasus 53,95 \% lakilaki dan $46,05 \%$ perempuan dengan crude fatality rate (CFR) $7,6 \%$, paling tinggi bila dibandingkan dengan penyakit lainnya. ${ }^{1,2,3}$ Prokalsitonin (PCT) sebagai salah satu biomarker telah menunjukan toleransi yang baik dan efektif untuk evaluasi dan mengurangi penggunaan terapi antibiotik serta dapat menggambarkan beratnya infeksi bakteri sistemik. Prokalsitonin pertama kali digambarkan sebagai tanda spesifik infeksi bakteri. Kepekaan serum PCT meningkat saat inflamasi sistemik, khususnya ketika hal tersebut disebabkan 
oleh bakteri. Kegunaan serum petanda terhadap infeksi sistemik seperti $C$-reaktiv protein (CRP) atau PCT untuk diagnosis banding menjadi pembicaraan yang menarik beberapa tahun ini. Prokalsitonin merupakan salah satu petanda sepsis yang akurat. Kadar serum PCT atau petanda infeksi bakteri lain mungkin bisa membantu penentuan terapi antibiotik pada pasien pneumonia., $3,5,6$

\section{PNEUMONIA}

Pneumonia didefmisikan sebagai suatu peradangan akut parenkim paru yang disebabkan oleh mikroorganisme (bakteri, virus, jamur, parasit). Pneumonia yang disebabkan oleh Mycobacterium tuberculosis tidak termasuk. Peradangan paru yang disebabkan oleh nonmikroorganisme (bahan kimia, radiasi, aspirasi bahan toksik, obat-obatan dan lain-lain) disebut pneumonitis. Gejala yang terjadi pada penumonia biasanya ditandai dengan demam, menggigil, batuk dengan dahak mukoid atau purulen kadang disertai darah, sesak napas dan nyeri dada. Pemeriksaan fisis dapat ditemukan peningkatan suhu tubuh melebihi $38^{\circ} \mathrm{C}$, pada auskultasi terdengar suara napas bronkovesikuler sampai bronkial yang mungkin disertai ronki basah halus. Foto toraks (postero anterior/lateral) merupakan pemeriksaan penunjang utama untuk menegakkan diagnosis. Gambaran radiologis dapat berupa infiltrat sampai konsolidasi. Pada pemeriksaan laboratorium terdapat peningkatan jumlah leukosit, biasanya lebih dari 10.000/ul kadang-kadang mencapai 30.000/ul, dan pada hitung jenis leukosit terdapat pergeseran ke kiri. Untuk menentukan diagnosis etiologi diperlukan pemeriksaan dahak, kultur darah dan serologi. Pneumonia diklasifikasikan berdasarkan klinis dan epidemiologis, pneumonia komunitas (CAP), pneumonia didapat di rumah sakit (Hospital -Acquired Pneumonia atau HAP), Health Care Associated Pneumonia (HCAP) dan pneumonia akibat pemakaian ventilator (Ventilator Associated Pneumonia atau VAP). ${ }^{1,7,8}$

\section{PATOGENESIS}

Mekanisme pertahanan paru pada orang sehat akan menyebabkan tidak terjadi pertumbuhan mikroorganisme di paru. Ketidakseimbangan antara daya tahan tubuh, mikroorganisme dan lingkungan yang terjadi akan menyebabkan mikroorganisme berkembang biak dan mencapai saluran napas. Ukuran mikroorganisme/bakteri penyebab pneumonia berukuran 0,5-2,0 urn biasanya masuk secara inhalasi atau aspirasi. Mikroorganisme patogen ini akan berkembang biak di dalam atau pada epitel saluran napas dan menimbulan reaksi radang berupa edema seluruh alveoli disusul dengan infiltrasi sel poli morfo nuklear (PMN) dan diapedesis eritrosit sehingga terjadi permulaan fagositosis sebelum terbentuk antibodi, peningkatan sekresi mukus, mengurangi fungsi mukosilier dan mengganggu fungsi paru. Bakteri yang masuk ke paru masuk ke bronkioli dan alveoli menimbulkan reaksi peradangan yang menghasilkan cairan kaya protein dalam alveoli dan jaringan interstitial. Pada tahap awal terjadi proses hepatisasi merah yaitu perembesan eritrosit dan beberapa leukosit dari kapiler paru. Pada tingkat lebih lanjut aliran darah menurun, alveoli penuh dengan leukosit, kuman difagositosis kemudian makrofag masuk ke alveoli, menelan leukosit dan kuman yang berada di dalamnya dan paru masuk dalam tahap hepatisasi abu-abu. Secara perlahan eritrosit yang mati dan eksudat dibuang dari alveoli terjadi resolusi sempurna dan paru kembali menjadi normal. ${ }^{1,10,11}$

\section{PNEUMONIA KOMUNITAS}

Pneumonia komunitas adalah peradangan akut pada parenkim paru yang didapat di masyarakat. Pneumonia dapat disebabkan oleh berbagai macam kuman, yaitu bakteri, virus, jamur dan protozoa. Penelitian di beberapa negara melaporkan bahwa bakteri gram positif penyebab utama pneumonia komunitas. Data dari beberapa rumah sakit di Indonesia tahun 2012 menunjukan bahwa penyebab terbanyak pneumonia 
komunitas di ruang rawat inap dari bahan sputum adalah kuman gram negatif seperti Klebsiella pneumoniae, Acinetobacter baumanii, Pseudomonas aeruginosa, sedangkan gram positif seperti Streptococcus pneumoniae, Streptococcus viridans, Staphylococcus aureus ditemukan dalam jumlah sedikit. Data survelans sentinel SARI (Severe Acute Respiratory Infection) 2010 yang dilakukan badan penelitian dan Pengembangan Kesehatan RI mendapatkan hasil biakan sputum yaitu Klebsiella pneumoniae (29\%), Acinetobacter baumanii (27\%), Staphylococcus aureus (16\%), Streptococcus pneumoniae (12\%), Acinobacter calcoaticus (8\%), Pseudomonas aeruginosa (6\%) dan Escherichia coli $(2 \%)^{1,9}$

Tabel 2. Pneumonia Severity Index (PSI)
Diagnosis pneumonia didapatkan dari anamnesis, pemeriksaan fisis, foto toraks dan laboratorium. Diagnosis pasti pneumonia komunitas ditegakkan jika pada foto toraks terdapat infiltrat / air bronchogram ditambah dengan beberapa gejala berikut ini yaitu batuk, perubahan karakteristik sputum/purulen, suhu tubuh $\geq$ $38^{\circ} \mathrm{C}$ (aksila)/riwayat demam, nyeri dada, sesak, pada pemeriksaan fisis dapat ditemukan tanda-tanda konsolidasi, suara napas bronkial dan ronki, leukosit $\geq$ 10.000 atau < 4500. Penilaian derajat keparahan penyakit pneumonia komunitas dapat dilakukan dengan menggunakan sistem skor menurut Pneumonia Severity Index (PSI) seperti terlihat pada tabel 2 dan CURB-65 (Confusion, Urea, Respiratory, Blood pressure, dan umur $\geq$ 65 tahun) seperti yang terlihat pada tabel 3 di bawah ini :

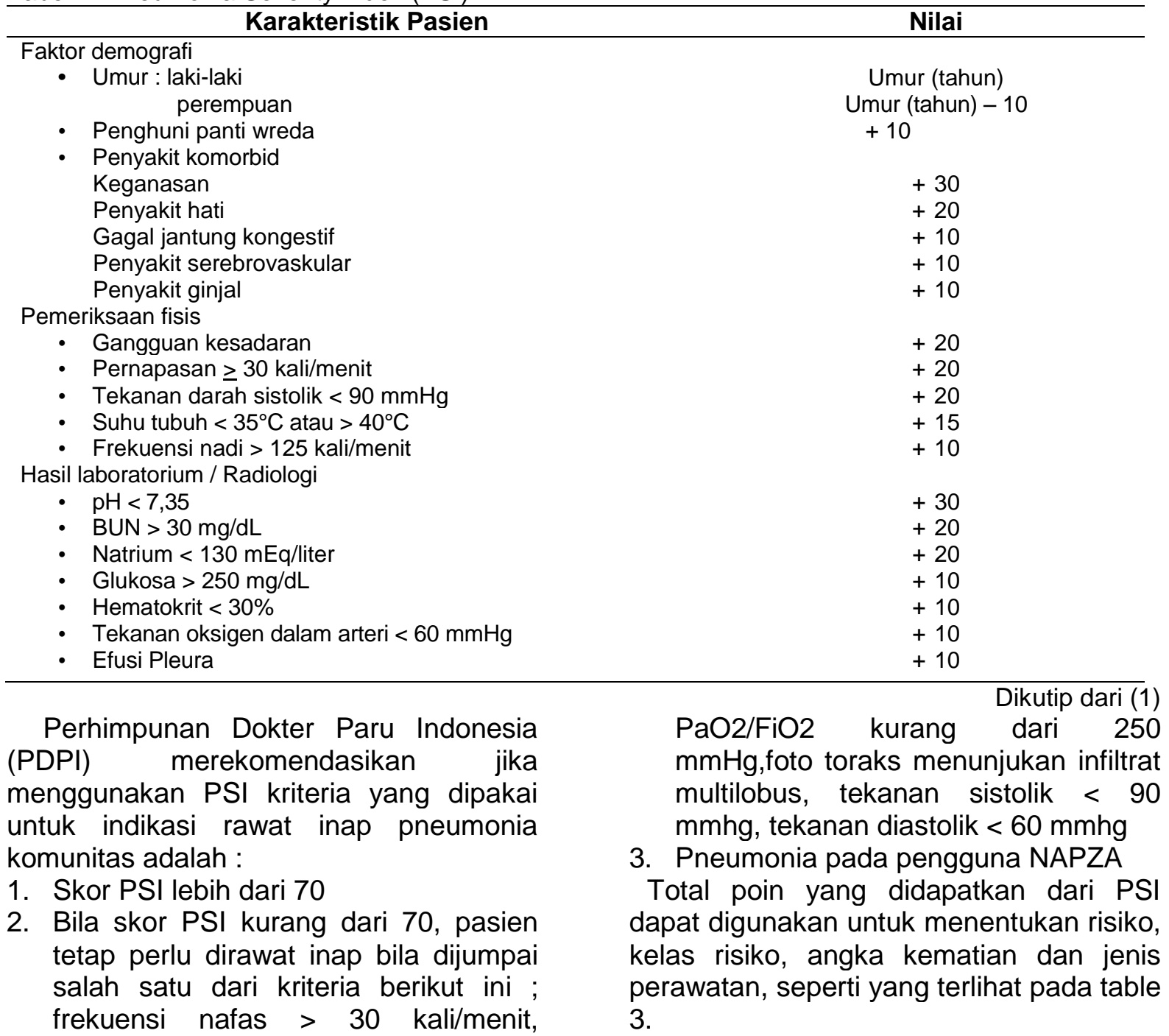


Tabel 3. Derajat skor risiko PSI

\begin{tabular}{ccccc}
\hline Total Poin & Risiko & Kelas Risiko & Angka Kematian & Perawatan \\
\hline Tidak & Rendah & I & $0.1 \%$ & Rawat jalan \\
diprediksi & & & & \\
$<70$ & & II & $0.6 \%$ & Rawat jalan \\
$71-90$ & & III & $2.8 \%$ & Rawat inap/jalan \\
$91-130$ & Sedang & IV & $8.2 \%$ & Rawat inap \\
$>130$ & Berat & V & $29.2 \%$ & Rawat inap \\
\hline
\end{tabular}

Dikutip dari (1)

Skor CURB-65 adalah penilaian terhadap setiap faktor risiko yang diukur. Sistem skor pada CURB-65 lebih ideal digunakan untuk mengidentifikasi pasien dengan tingkat angka kematian tinggi. Setiap nilai faktor risiko dinilai satu, faktor tersebut yaitu Confusion yaitu tingkat kesadaran berdasarkan uji mental, Urea, frekuensi napas, tekanan darah dan umur $\geq 65$ tahun. Tingkat kesadaran dinilai berdasarkan Abbreviation Mental Test (uji mental), terdapat 10 pertanyaan yg tiap pertanyaan bernilai 1 . Setelah didapatkan nilai untuk confusion maka kemudian dinilai yang lainnya yaitu urea, frekuensi napas, tekanan darah dan umur. Mengingat keterbatasan BUN (Blood Urea Nitrogen) maka digunakan pemeriksaan ureum yang dengan mengkonversikan nilai ureum dengan membagi 2,14. Bila nilai urea $>19 \mathrm{mg} / \mathrm{dL}$ maka diberi nilai 1 dan nilai urea $\leq 19$ $\mathrm{mg} / \mathrm{dL}$ dibei nilai 0 . Total nilai dari faktor risiko digunakan untuk menentukan apakah pasien dapat berobat jalan atau rawat inap, dirawat di ruangan biasa atau ruang intensif. Skor CURB-65 terlihat pada tabel 4.

Tabel 4. Skor CURB-65

Confusion

- $\quad$ Uji mental $\leq$ nilai 8 skor 1

Urea

- Uji mental > nilai 8 skor 0

- Urea $>19 \mathrm{mg} / \mathrm{dL}$ skor 1

- Urea $\leq 19 \mathrm{mg} / \mathrm{dL}$ skor 0

Respiratory rate (frekuensi nafas)

- $\quad R R>30 x / m n t$ skor 1

- RRS30x/mnt skor 0

Blood pressure (tekanan darah)

- Tekanan darah $<90 / 60$ mmhg skor 1

- Tekanan darah $\geq 90 / 60$ mmhg skor 0

Umur

Umur $\geq 65$ tahun skor 1

Umur $<65$ tahun skor 0
Penilaian berat pnumonia dengan menggunakan sistem skor CURB-65 adalah sebagai berikut :

Skor 0-1 : risiko kematian rendah, pasien dapat berobat jalan

Skor 2 : risiko kematian sedang, dapat dipertimbangkan rawat jalan

Skor 3 : risiko kematian tinggi dan dirawat harus di tatalaksana sebagai pneumonia berat

Skor 4 atau 5 : harus dipertimbangkan perawatan intensif

\section{PROKALSITONIN}

Prokalsitonin pertama kali dikenali dari sel karsinoma medula tiroid yang terdiri dari 116 asam amino yang memiliki susunan yang identik dengan prohormone kalsitonin dengan berat molekul $13 \mathrm{kDa}$ protein, yang disandi oleh gen CALC-1 di lengan pendek kromosom 11. Urutan asam amino prokalsitonin pertama kali ditemukan oleh Moullec et al. tahun 1984. Secara normal proklsitonin akan dipecah oleh sel neuroendokrin yang terdapat pada kelenjar tiroid, paru dan pankreas sehingga menghasilkan 3 jenis molekul yaitu kalsitonin, katacalcin dan amino-procalcitonin yang terlihat pada gambar 1. Kepekatan serum PCT sangat rendah pada orang sehat yaitu $<0.1$ $\mathrm{ng} / \mathrm{mL}^{5,12-14}$ 


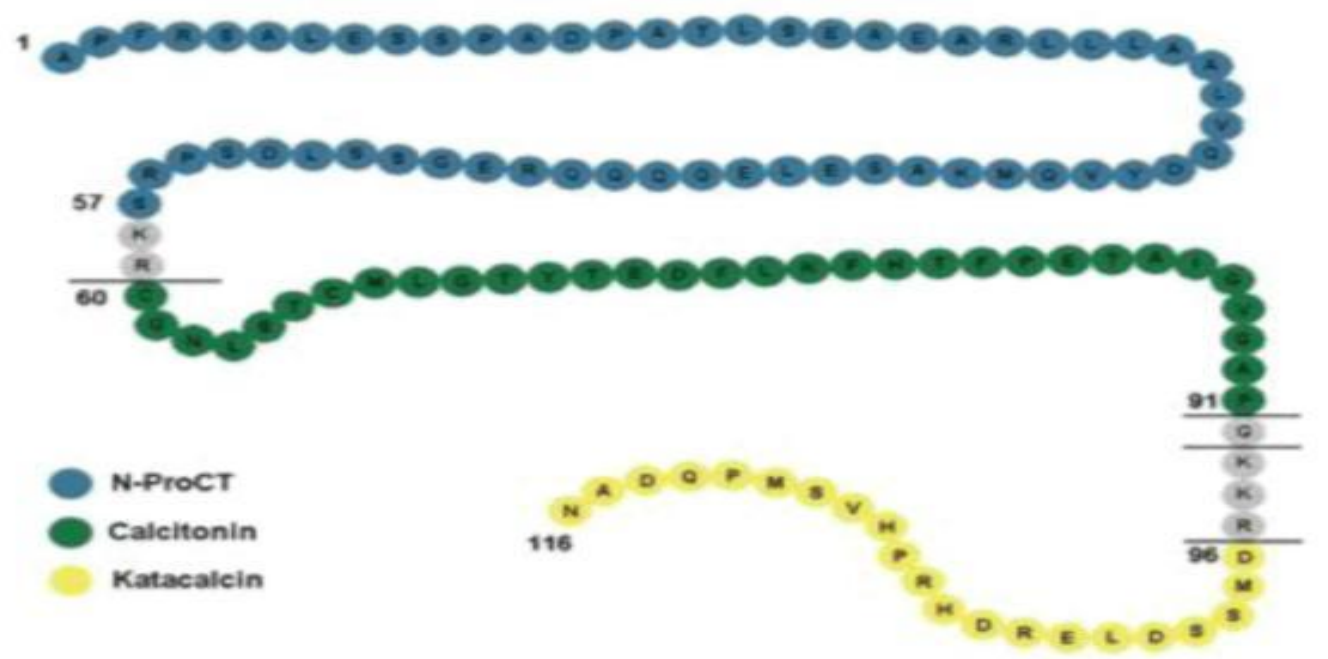

Gambar 1. Strktur primer polipeptida 116 prekusor kalsitonin

Prokalsitonin diinduksi oleh endotoksin yang dihasilkan bakteri selama infeksi sistemik. Infeksi yang disebabkan oleh protozoa, infeksi non bakteri (virus) dan penyakit autoimun tidak menginduksi PCT. Produksi plasma PCT dapat diinduksi dari manusia sehat dengan injeksi lipopolisakarida (LPS) dalam kadar yang kecil. Kadar PCT meningkat cepat dalam 2 jam setelah rangsangan, puncaknya setelah 12-48 jam dan secara perlahan menurun dalam 48-72 jam. Induksi yang spesifik dan cepat oleh stimulus yang adekuat akan menimbulkan produksi PCT pada pasien infeksi berat atau sepsis, sedangkan CRP tidak terdapat dalam 6 jam. ${ }^{5,18}$ Prokalsitonin termasuk kelompok yang terkait protein termasuk kalsitonin, amylin, adrenomodulin (CAPA peptide family). Prokalsitonin secara normal diproduksi sel C kelenjar tiroid. Kondisi normal PCT tidak dilepas ke dalam darah dan kadar PCT serum sangat rendah pada individu yang sehat yaitu $<0,1 \mathrm{ng} / \mathrm{ml}$. Selama infeksi sistemis, PCT diproduksi oleh jaringan lain dan kadarnya meningkat pada kondisi infeksi berat, infeksi bakteri dan infeksi jamur. Saat ini PCT merupakan petanda sepsis walaupun demikian beberapa penelitian menemukan peningkatan PCT juga pada kasus pembedahan, trauma, syok kardiogenik dan kondisi lain. ${ }^{5,13}$

Prokalsitonin pada orang sehat diubah dan tidak ada sisa yang bebas ke aliran darah, sehingga kadar PCT tidak dapat terdeteksi $(<0.1 \mathrm{ng} / \mathrm{ml})$. Pada keadaan infeksi berat yang bermanifestasi sistemik, kadar PCT meningkat hingga melebihi 100 $\mathrm{ng} / \mathrm{ml}$. Waktu paruh PCT terjadi antara 2530 jam yang secara signifikan tidak berubah pada gagal ginjal, sehingga kepekatan serum dapat digunakan untuk tujuan diagnostik pada penderita dengan fungsi ginjal yang rusak. Hal ini berbeda dengan waktu paruh calsitonin yang hanya 10 menit. Pada keadaan inflamasi akibat bakteri, kadar PCT selalu $>2 \mathrm{ng} / \mathrm{ml}$. Kasus akibat infeksi virus, kadar PCT $>0.05 \mathrm{ng} / \mathrm{ml}$ tetapi biasanya $<1 \mathrm{ng} / \mathrm{ml} .^{5,15,16}$

Prokalsitonin diukur pada serum dengan menggunakan pemeriksaan iunoluminometrik. Pemeriksaan menggunakan dua antibodi monoklonal antigen spesifik, satu diarahkan ke calcitonin (menggunakan label luminescence) dan yang lainnya ke katacalcin. Batas untuk mengetahui pemeriksaan adalah $0.1 \mathrm{ng} / \mathrm{ml}$ dan koefisien variasinya 5 sampai dengan $10 \%$ dengan rentang 1 sampai dengan $1000 \mathrm{ng} / \mathrm{ml}$. Pemeriksaan juga tidak dipengaruhi antibiotika, sedatif dan agen vasoaktif yang secara umum digunakan dalam unit perawatan intensif. Interpretasi PCT setelah pemberian antibiotika menunjukkan keberhasilan bila kadar PCT turun $50 \%$, tetapi bila tetap atau kadar PCT meningkat, berarti tidak ada perubahan dengan pengobatan. Kadar PCT pada berbagai keadaan inflamasi dapat terlihat pada tabel $3 .^{5}$ 
Tabel 3. Kadar PCT pada berbagai keadaan inflamasi

\begin{tabular}{ll}
\hline \multicolumn{1}{c}{ Kondisi } & \multicolumn{1}{c}{ Kadar PCT $(\mathrm{ng} / \mathrm{ml})$} \\
\hline Normal & $<0.5$ \\
Inflamasi kronik dan penyakit autoimun & $<0.5$ \\
Infeksi Virus & $<0.5$ \\
SIRS, multiple trauma, luka bakar & $0.5-2$ \\
Infeksi berat, sepsis, kegagalan beberapa organ & $>2$ (paling sering 10-100) \\
\hline
\end{tabular}

Dikutip dari (5)

\section{Prokalsitonin dibandingkan dengan petanda inflamasi lain}

Beberapa penelitian menyebutkan bahwa PCT lebih sensitif dan spesifik untuk mendiagnosis infeksi dibandingan dengan CRP, interleukin (IL)-6 dan IL-8 pada beberapa situasi klinis. Prokalsitonin akan meningkat dengan cepat pada fase awal terjadi infeksi dan cepat menurun setelah infeksi tertangani dengan penggunaan antibiotik. Stimulus untuk transkripsi gen dan sekresi PCT baik secara langsung melalui racun mikroba dan tidak langsung melalui mediator inflamasi, seperti Interleukin (IL)-1, IL-6 dan faktor- $\alpha$ nekrosis tumor (TNF- $\alpha){ }^{5}$ Sitokin seperti TNF- $\alpha$ dan IL-6 akan meningkat 1-3 jam pertama setelah proses inflamasi dan tetap tinggi hingga 8 jam. Hiperprokalsitoninemia pada peradangan sistemik atau infeksi terjadi selama 2-4 jam dan mencapai konsentrasi puncak dalam 8-24 jam selama proses peradangan berlanjut. Waktu paruh PCT adalah sekitar 24 jam, sehingga konsentrasi mencapai normal secara cepat dengan pemulihan pasien. $C$ reactive protein adalah reaktan fase akut yang pengukurannya seringkali digunakan untuk diagnosis infeksi bakteri. Hati mensintesis CRP sebagai respons terhadap IL-6 saat infeksi atau inflamasi dengan cara mengikat lipopolisakarida patogen. ${ }^{12,17}$ Peningkatan kadar CRP membutuhkan waktu 12-24 jam dan menetap selama 3-7 hari dengan cut off point $6 \mathrm{mg} / \mathrm{l}^{13,16}$

\section{Peranan Prokalsitonin pada pneumonia komunitas}

Penilaian derajat keparahan penyakit pneumonia komunitas dengan menggunakan PIS dan CURB-65 telah diakui peranannya dan dianggap tepat sebagai sarana prognostik oleh berbagai pedoman bagian infeksi respirasi. Skor untuk menilai risiko klinis ini mempunyai keterbatasan dalam penggunaannya secara praktis dan dapat terjadi kesalahan dalam perhitungan pada pasien dengan populasi berbeda. Prokalsitonin dianggap sebagai sarana prognostik tambahan yang baru dan menarik sebagai biomarker yang objektif dan pengukurannya dilakukan secara cepat dan respons yang cepat terhadap penyembuhan yang signifikan, reliable dengan informasi yang yang dapat diketaui langsung setelah pemeriksaan. Suatu penelitian di Amerika secara kohort pada pasien CAP yang diperiksa kadar PCT memberikan hasil yang baik, pada pasien yang diklasifikasikan risiko tinggi menggunakan skor PSI dengan nilai PCT $\leq 0,1 \mathrm{ngr} / \mathrm{L}$ pada dasarnya mengeksklusi risio kematian terhadap pasien dengan risiko tinggi tersebut. $^{2}$

Suatu penelitian serupa di Jerman terhadap pasien CAP dengan risiko rendah, menemukan bahwa PCT dapat dijadikan alat prediksi kematian dan kesakitan yang akurat serta secara signifikan dapat menilai perbaikan dari skor derajat keparahan penyakit CAP. Kadar di dalam serum akan meningkat secara cepat pada infeksi bakteri tapi lambat pada penyakit virus. Beberapa penelitian menyebutkan bahwa PCT lebih tinggi pada bakteri gram negatif dibadingkan dengan bakteri gram positif. ${ }^{2,3}$ Penelitian yang dilakukan di India pada tahun 2011-2013 yang bertujuan membandingkan kegunaan PCT, CRP dan jumlah total leukosit dengan nilai derajat keparahan penyakit PSI dan CURB65, mendapatkan hasil bahwa PCT merupakan prediktor yang lebih baik dalam memprediksa kematian daripada PSI dan CURB65 pada pasien dengan risiko tinggi. Pasien dengan $\mathrm{PCT}<0,25$ ngr/L mempunyai risiko rendah pada kematian dalam 30 hari. $^{8}$ 
Prokalsitonin akan menjadi meningkat selama infeksi bakteri dan menurun sejalan dengan perbaikan klinis pasien. Hal ini dapat membantu menentukan kepentingan pemberian $A B$ dan durasinya. Terdapat 14 penelitian yang mengevaluasi efikasi dan keamanan penggunaan PCT untuk keputusan pemberian antibiotik berdasarkan nilai PCT. Semua penelitian tersebut menggunakan protokol yang serupa untuk memulai dan menghentikan terapi antibiotik berdasarkan nilai PCT. Beberapa batasan titik potong PCT digunakan pada penelitian yang menggambarkan peningkatan kadar PCT pada penyakit yang disebabkan bakteri. Protokol pada penelitian tersebut menggambarkan cutt off berdasarkan keadaan klinis dan tingkat akut atau tidaknya keadaan pasien. Pada keadaan pasien dengan derajat akut yang rendah, (misalnya pada pelayanan kesehatan primer dan pada bronkitis), PCT utamanya digunakan untuk menilai keputusan pemberian antibiotik atau menundanya, sebaliknya pada keadaan infeksi saluran napas yang berat (misalnya pneumonia yang dirawat inap di RS) atau derajat akut yang lebih berat (misalnya sepsis atau syok sepsis di ICU), PCT digunakan untuk tidak menentukan mulainya pemberian antibiotik, namun untuk menghentikan antibiotik.

Semua pasien akan dinilai ulang dalam hal penghentian antibiotik atau apabila kondisi klinis tidak ada perbaikan dalam 12 hari. Pada penelitian tersebut strategi itu terbukti sangat efektif untuk mengurangi penggunaan antibiotik. Pada derajat akut yang rendah, petunjuk PCT menunjukkan $40 \%-75 \%$ pada pasien pelayanan primer dengan infeksi saluran napas atas dan bawah, 60\%-75\% pada pasien bronkhitis, $30 \%-45 \%$ pada pasien PPOK eksaserbasi. Pada keadaan derajat akut yang lanjut, petunjuk PCT mengurangi durasi terapi $35 \%-55 \%$ pada pasien CAP dan $35 \%$ pasien VAP. ${ }^{2,3}$

Penelitian Simon dkk. ${ }^{14}$ dilakukan untuk membedakan antara infeksi bakteri dengan inflamasi non bakterial. Prokalsitonin mempunyai sensitifitas yang lebih tinggi ( $88 \%$ vs. $75 \%$ ) dan spesifisitas yang juga lebih tinggi (81\% vs. 67\%) dibandingkan dengan CRP. Selain itu, penelitian dilakukan untuk membedakan antara infeksi bakteri dan virus prokalsitonin menunjukkan sensitifitas yang lebih tinggi $(92 \%$ vs. $86 \%)$ sedangkan spesifisitasnya sebanding (73\% vs.70\%). ${ }^{16}$ Hasil penelitian yang dilakukan oleh Polzin dkk. ${ }^{26}$ menunjukkan prokalsitonin pada pasien dengan CAP atau HAP dan pasien yang dirawat dengan PPOK eksaserbasi dibanding kontrol orang sehat. Nilai median prokalsitonin lebih rendah dari cutt-off point $0,5 \mathrm{ng} / \mathrm{ml}$ sedangkan Hedlund dan Hansson memperlihatkan dengan nilai cutt-off point $0,5 \mathrm{ng} / \mathrm{ml}$ dapat membedakan etiologi bakteri atau atipik pada pasien dewasa yang dirawat dengan CAP. ${ }^{18}$

Schleicher GK dkk. ${ }^{19}$ mendapatkan pada pasien dengan Human Immunodeficiency Virus (HIV) positif dengan CAP memiliki peningkatan kadar PCT dan CRP dibanding dengan pasien yang menderita tuberkulosis. Peningkatan level prokalsitonin merupakan penanda spesifik sepsis disebabkan bakteri pada pasien HIV positif. Berbeda dengan CRP, PCT tidak spesifik meningkat pada pasien tuberkulosis paru, sehingga dapat digunakan sebagai alat diagnostik cepat dalam membedakan infeksi bakteri dengan mycobacterial. Kadar prokalsitonin $>3 \mathrm{ng} \cdot \mathrm{ml}^{-1}$ dan $\mathrm{CRP}>246 \mathrm{mg} \cdot \mathrm{L}^{-1}$ merupakan tanda infeksi pneumonia dan dapat menuntun diagnosis yang tepat. ${ }^{15}$ Crain $\mathrm{C}$ dkk. ${ }^{20}$ mengungkapkan bahwa PCT dapat digunakan sebagai pedoman strategi terapi dan berfungsi mengurangi penggunaan antibiotik pada infeksi saluran napas bawah, karena PCT dapat membedakan pasien dengan atau tanpa gejala klinis infeksi bakteri. Penelitian ini melibatkan 243 pasien pneumonia, bronkitis akut, asma atau gangguan penyakit pernapasan yang dibagi menjadi 2 kelompok. Kelompok pertama mendapat pengobatan standar sebanyak 119 orang dan kelompok yang menggunakan PCT sebagai acuan terapi sebanyak 124 orang kemudian dari kelompok yang menggunakan PCT sebagai acuan dibagi lagi menjadi kelompok yang mendapat antibiotik bila kadar PCT $>0,25 \mathrm{ng} / \mathrm{ml}$ dan kelompok yang tidak mendapat antibiotik bila kadar PCT $<0,25 \mathrm{ng} / \mathrm{ml}$. Hasil penelitian ini menyatakan tidak ada 
perbedaan hasil pengobatan secara klinis dan laboratorium antara 2 kelompok dan ditemukan pengurangan penggunaan antibiotik sebanyak $39 \% .^{20,21}$

\section{KESIMPULAN}

1. Prokalsitonin adalah prekursor kalsitonin yang berfungsi sebagai pro hormone dan berperan pada proses inflamasi.

2. Prokalsitonin tidak dapat mengidentifikasi secara spesifik penyebab infeksi, namun bakteri patogen akan meningkat secara signifikan dengan peningkatan nilai PCT.

3. Kadar prokalsitonin serum sangat rendah pada individu sehat dan kadarnya meningkat pada kondisi infeksi berat dan infeksi bakteri.

4. Prokalsitonin dapat digunakan sebagai petanda prognostik dan pedoman strategi terapi, sehingga dapat mengurangi penggunaan antibiotik pada infeksi saluran napas bawah khususnya pneumonia.

5. Prokalsitonin dapat mengeksklusi penyebab infeksi dan sebagai informasi tambahan dalam perkembangan perbaikan klinis pasien dan terkait dengan hasil biakan darah pasien.

6. Prokalsitonin merupakan petanda yang akurat untuk menentukan infeksi yang disebabkan oleh bakteri.

7. Pada infeksi pernapasan akut akan terjadi peningkatan kadar prokalsitonin secara signifikan.

\section{DAFTAR PUSTAKA}

1. Soepandi PZ, Burhan E, Nawas A, Giriputro S, Isbaniah F, Agustin H, et al. Pneumonia komunitas. Jakarta : PDPI;2014:1-19.

2. Schuetz P, Amin DN, Greenwald JL, Role of procalcitonin in managing adult patient with respiratory tract infection. Chest. 2012;141(4):106373.

3. Schuetz $P$, Litke A, Albrich WC, Mueller B. Blood biomarker for personalized management decisionsb in community acquired pneumonia. Curr Opin Infect Dis. 2013;26:159-67.

4. Sudoyo AW, Setiyohadi B, Alwi I. Pneumonia. IImu Penyakit Dalam. Jakarta : Penerbit; IPD FKUI;2006:965-71.

5. Buchori, Prihartini. Diagnosis sepsis menggunakan prokalsitonin. Indonesian Journal of linical Pathology and Medical Laboratory. 2006;12(3):131-7.

6. Masia M, Gutiérrez $F$, Shum $C$, Padilla S, Navarro JC, Flores E, et al. Usefulness of procalcitonin levels in community acquired pneumonia according to the patients outcomes research team pneumonia severity index. Chest. 2005;128:2223-9.

7. Mandell LA, Wunderink RG, Azueto A. Infectious Diseases Society of America/American Thoracic Society consensus guidelines on the management of community-acquired pneumonia in adults: Clin Infect Dis. 2007;44:s27-72.

8. Agarwal S, Meena M, Misra A, Meena L, Singh M. A study to compare prognostic utility of procalcitonin with existing biomarkers (CRP and TLC) and clinical risk score (PSI and CURB65) in community acquired pneumonia. National Journal of Physiology, Pharmacy \& Pharmacology. 2015;5:28-32.

9. Mandell L, Marrie T, Grossman R. Canadian guidelines for the initial management of community acquired pneumonia: an evidence based update by the Canadian Infectious Disease Society and the Canadian Thoracic Society. Clin Infect Dis. 2000;31:383-421.

10. Dasaraju PV, Liu C. Infections in respiratory system. [cited on January, 1st 2009]. Available from :.

11. Wunderink http://gsbs.utmb.edu/ microbook/ch093.htm RG. A CAP on antibiotic duration. Am J Respir Crit Care Med. 2006;174:3-5.

12. Becker KL, Nyle'n ES, White JC, Muller B, Snider RH. Procalcitonin and the calcitonin gene family of peptides in inflammation, infection and sepsis : a journey from calcitonin 
back to its precursors. $\mathrm{J}$ Clin Endocrinol Metab. 2004;89:1512-25.

13. Kristopher AM, Baumann NA. Clinical laboratory news: procalcitonin. AACC. 2009; 35(7).

14. Kibe S, Adams K, Barlow G, Diagnostic and prognostic biomarkers of sepsis in clinical care. J.Antimicrob Chemoter. 2011;66(suppl 2):i33-40.

15. Vienna. Procalcitonin: a new marker of the systemic inflammatory response to infections. Clinic Anesthestiology and Intensive Care. Germany. April. 2000.

16. Korppi M, Remes S. Serum prokalsitonin in pneumococcal pneumonia in children. Eur Respir J.2001;17:623-7.

17. Kiriyama Y, Nomura Y, Tokumitsu Y. Calcitonin gene expression induced by lipopolysaccharide in the rat pituitary. Am J Physiology Endocrinol Metab. 2002;282:1380-4.

18. Polzin A, Pletz $M$, Erbes $R$, Raffenberg $M$, Mauch $\mathrm{H}$, Wagner $\mathrm{S}$ et al. Procalcitonin as a diagnostic tool in lower respiratory tract infections and,tuberculosis. Eur Respir J. 2003;939-4.

19. Schleicher GK. Procalcitonin and Creactive protein levels in HIVpositive subject with tuberculosis and pneumonia. Eur Respir J.2005;25:688-92.

20. Crain C, Stolz DJ, Bingisser R, Gencay MM, Huber PR, Tamm M et al. Effect of procalcitonin-guided treatment on antibiotic use and outcome in lower respiratory tract infections:clusterrandomised,singleblinded interventional trial. Lancet. 2004; 363:600-7.

21. Crain MC. Procalcitonin guidance of antibiotic therapy in community acquired pneumonia. Am J Respir Crit Care Med. 2006;174:84-93 